\title{
Interorganizational knowledge transfer mechanisms: a study in the largest Brazilian institution of agricultural research
}

\author{
DANIELA MARTINS DINIZ ${ }^{1}$ \\ FABRICIO MOLICA DE MENDONÇA ${ }^{1}$ \\ FÁtIMA BAYMA DE OLIVEIRA ${ }^{2}$ \\ ANDERSON DE SOUZA SANT'ANNA ${ }^{3}$
}

${ }^{1}$ Universidade Federal de SÃo JoÃo del ReI (UFSJ) / Departamento de CIÊNCIAS AdMINISTRATIVAS E ConTÁBEIS, SÃO JOÃO DEL REI - MG, BRAZIL

2 Fundação Getulio Vargas (FGV ebape) / Escola Brasileira de Administração Pública e de EMpresas, Rio de JANEIRo - RJ, BRAZIL

${ }^{3}$ Fundação Getulio Vargas (FGV EAESP) / Escola de AdministraçÃo de EMPreSAS de SÃo Paulo, SÃo PaUlo - SP, BRAZIL

\section{Abstract}

Based on the theoretical perspective of interorganizational knowledge transfer, the objective of the study was to analyze the role of mechanisms in the performance of knowledge transfer between a Brazilian public research institution and its licensed companies. In methodological terms, qualitative research was carried out based on the case study method applied in the largest national institution of public agricultural research. The results of the study point out that, despite the diversity of available mechanisms, the knowledge transfer between the Research Institution and the licensed companies is characterized by the intensive use of coding mechanisms rather than customization mechanisms, which are fundamental in transfer of tacit knowledge. These findings converge with studies in the field that indicate that the sharing of tacit knowledge requires the use of personalization mechanisms and that, in the absence of adequate mechanisms, technology transfer tends to face considerable challenges, such as the emergence of relational conflicts in the partnership and the difficulty of applying the technology by the receiving companies, inhibiting the process innovation potential. Therefore, a relevant implication is that the transfer of interorganizational knowledge should be conceived as a relational process that requires joint learning, especially when the type of knowledge involved has a complex nature.

Keywords: Knowledge Transfer. Interorganizational Relationships. Transfer Mechanisms. Agricultural Technologies.

\section{Mecanismos de transferência de conhecimento interorganizacional: um estudo na maior instituição brasileira de pesquisa agropecuária}

\section{Resumo}

Baseando-se na perspectiva teórica da transferência de conhecimento interorganizacional, este estudo teve como objetivo analisar o papel dos mecanismos no desempenho da transferência de conhecimento entre uma instituição brasileira de pesquisa pública e suas empresas licenciadas. Em termos metodológicos, foi realizada pesquisa de natureza qualitativa com base no método de estudo de caso aplicado na maior instituição pública de pesquisa agropecuária do Brasil. Os resultados do estudo apontam que, a despeito da diversidade de mecanismos disponíveis, a transferência de conhecimento entre a instituição de pesquisa e as empresas licenciadas é caracterizada pelo uso intensivo de mecanismos de codificação ao invés de mecanismos de personalização, os quais são fundamentais na transferência de conhecimento tácito. Tais achados convergem com estudos na área que sinalizam que o compartilhamento de conhecimento tácito requer o uso de mecanismos de personalização e que, na ausência de mecanismos adequados, a transferência tecnológica tende a enfrentar desafios consideráveis, como a emergência de conflitos relacionais entre as partes e a dificuldade de aplicação da tecnologia pelas empresas receptoras, inibindo o potencial de inovação do processo. Portanto uma implicação relevante é a de que a transferência de conhecimento interorganizacional deve ser concebida como um processo relacional que requer aprendizagem conjunta, sobretudo, quando o tipo de conhecimento envolvido possui natureza complexa.

Palavras-chave: Transferência de Conhecimento. Relações Interorganizacionais. Mecanismos de Transferência. Tecnologias Agropecuárias.

\section{Mecanismos de transferencia de conocimiento interorganizacional: un estudio en la mayor institución bra- sileña de investigación agropecuaria}

\section{Resumen}

Con base en la perspectiva teórica de la transferencia de conocimiento interorganizacional, este estudio tiene como objetivo analizar el papel de los mecanismos en el desempeño de la transferencia de conocimiento entre una institución brasileña de investigación pública y sus empresas licenciadas. En términos metodológicos, se realizó una investigación de naturaleza cualitativa con base en el método de estudio de caso aplicado en la mayor institución brasileña de investigación pública agropecuaria. Los resultados del estudio apuntan que, a pesar de la diversidad de mecanismos disponibles, la transferencia de conocimiento entre la institución de investigación y las empresas licenciadas se caracteriza por el uso intensivo de mecanismos de codificación en lugar de mecanismos de personalización, que son fundamentales en transferencia de conocimiento tácito. Tales hallazgos convergen con diversos estudios en el área que señalan que el compartir de conocimiento tácito requiere el uso de mecanismos de personalización y que, en ausencia de mecanismos adecuados, la transferencia tecnológica tiende a enfrentar desafíos considerables, como la emergencia de conflictos relacionales entre las partes y la dificultad de aplicación de la tecnología por las empresas receptoras, inhibiendo el potencial de innovación del proceso. Por lo tanto una implicación relevante es que la transferencia de conocimiento interorganizacional debe ser concebida como un proceso relacional que requiere aprendizaje conjunto, sobre todo, cuando el tipo de conocimiento involucrado tiene naturaleza compleja.

Palabras clave: Transferencia de conocimiento. Relaciones interorganizacionales. Mecanismos de transferencia. Tecnologías agropecuarias

Article submitted on June 23, 2018 and accepted for publication on January 03, 2019.

[Translated version] Note: All quotes in English translated by this article's translator.

DOI: http://dx.doi.org/10.1590/1679-395175538x 


\section{INTRODUCTION}

The researches in the field of theory of organizations, from the decade of 1990, has focused on "knowledge" in a series of studies especially related to learning, knowledge management and innovation (GRANT, 2002; NONAKA and VON KROGH, 2009). The increase in interest in this subject stems from that knowledge is one of the critical resources of organizations and that their ability to generate new knowledge manage and use them successfully is one of the decisive factors for the competitiveness of organizations in the current business context (KOGUT and ZANDER, 1993; ARGOTE and INGRAM, 2000; GRANT, 2002; NONAKA and VON KROGH, 2009; ARGOTE and MIRON-SPEKTOR, 2011; DINIZ, 2011).

In this context, one of the processes that has emerged as an important way of acquiring new knowledge and innovating is the interorganizational knowledge transfer (PÉREZ-NORDTVEDT, KEDIA, DATTA et al., 2008; VAN WIJK, JANSEN and LYLES, 2008; MARTINKENAITE, 2011; BOZEMAN, RIMES and YOUTIE, 2015; BATTISTELLA, DE TONI and PILLON, 2016). On the one hand, transference is an innovation alternative for firms that are unable to develop a Research and Development (R \& $D)$ program internally because of its high cost, risk and uncertainty. On the other hand, the transfer is also relevant for firms that have an $R$ \& D program, since it provides economic sense to the innovation process. That is, it enables the organization to disseminate innovation in the productive sector and obtain the return on investment of the research carried out (LOVE and ROPER, 1999).

With the recognition of its role as a source of innovation, the transfer of interorganizational knowledge emerged in the 1990 s as a strategic theme in the organizational literature, and then became the subject of numerous studies (BOZEMAN, RIMES and YOUTIE, 2015; BATTISTELLA, DE TONI and PILLON, 2016). From this, a research agenda is consolidated whose main interests are related to the investigation of: a) actors involved in the transfer and their characteristics; b) factors that affect transfer performance, such as cultural distance between companies, motivation of the parties, absorptive capacity of the recipient, nature of the relationship, etc.); c) stages of the transfer process; d) channels or mechanisms through which knowledge is transferred; e) performance and results of the transfer (MARTINKENAITE, 2011; BOZEMAN, RIMES and YOUTIE, 2015; BATTISTELLA, DE TONI and PILLON, 2016).

Despite their importance as a source of innovation and competitiveness, several researches have evidenced the difficulties faced by organizations in conducting a successful knowledge transfer process. This situation can be the result of the action of several factors and mechanisms that, if not considered a priori, constitute barriers in the process and compromise their effectiveness (LARSSON, BENGTSSON, HENRIKSSON et al., 1998; CUMMINGS and TENG, 2003; MUTHUSAMY and WHITE, 2005; EASTERBY-SMITH, LYLES and TSANG, 2008; PÉREZ-NORDTVEDT, KEDIA, DATTA et al., 2008).

In relation to the role of mechanisms, the studies in the area point out that the intensity and quality of the interaction and knowledge flow between the parties, in the transfer of interorganizational knowledge, depends on the adequate selection of mechanisms, insofar as they represent the "bridge" or the "channels" through which the process is operationalized. In its absence, the transfer may fail due to cultural, relational and knowledge differences between the source and recipient companies, making it difficult to innovate in the process. Therefore, the performance of the interorganizational knowledge transfer process is significantly affected by the presence of mechanisms.

Nevertheless, studies in the area point out that the existing literature is still limited in explaining how source and receiver companies select adequate transfer mechanisms, as well as the influence of the nature of knowledge in the choice of these channels (CUMMINGS and TENG 2003; MARTINKENAITE, 2011; BOZEMAN, RIMES and YOUTIE, 2015; BATTISTELLA, DE TONI and PILLON, 2016). Therefore, it is necessary to consider the need for new research efforts aimed at understanding this phenomenon from the point of view of mechanisms.

In this context, with the present research, we sought to analyze, empirically, the role of mechanisms in the performance of the transfer of knowledge between a public agricultural public institution and its licensed companies. For that, it was necessary to identify and characterize the mechanisms of knowledge transfer used by the research institution and to analyze how the choice by certain types of mechanisms influences the performance of the knowledge transfer process.

Methodologically, qualitative research was conducted based on the case study method (YIN, 2005). The selected empirical object was one of the research centers of the largest public agricultural research institution in Brazil, whose mission is to develop and transfer new farming technologies to society, specifically corn seeds.

In terms of its theoretical relevance, the study seeks to empirically validate the important impact of mechanisms on the performance of interorganizational knowledge transfer. In addition to this, there is still no consensus on how to select and 
what criteria to consider in choosing the most effective mechanisms in interorganizational knowledge transfer processes and, therefore, new research efforts in the area may contribute, in some way, to minimize such theoretical gap (MARTINKENAITE, 2011; BOZEMAN, RIMES and YOUTIE, 2015).

In addition, the study is relevant considering an important sector of the Brazilian economy: agriculture and livestock. Historically, agribusiness has a relevant role in the socioeconomic scenario of the country, being one of the first activities developed in the Brazilian territory, representing 6\% of the Gross Domestic Product (GDP) of Brazil and generating employability for the economically active population of the country (IBGE, 2016). Finally, it is emphasized that the selected empirical object was the largest agricultural research institution in the country and the main generator of scientific and technological knowledge in this field.

After the contextualization of the research, the next topic presents the theoretical basis of the study.

\section{THEORETICAL REFERENCE}

\section{Interorganizational knowledge transfer}

Conceptually the transfer of interorganizational knowledge has been defined in several ways in the literature (BOZEMAN, RIMES and YOUTIE, 2015; BATTISTELLA, DE TONI and PILLON, 2016). Some researchers define transfer as the movement or flow of knowledge across organizational boundaries (EASTERBY-SMITH, LYLES and TSANG, 2008). Other authors use terms such as "access" or "acquisition" of new knowledge through external sources (BATTISTELLA, DE TONI and PILLON, 2016). Another definition associate's transference to interfirm learning processes (LARSSON, BENGTSSON, HENRIKSSON et al., 1998; POWELL, 1998; MUTHUSAMY and WHITE, 2005). There is also research that relates the transference to the diffusion of knowledge within networks of interorganizational relations (POWELL, 1998). Common points between these definitions are: a) the involvement of at least two organizations (process that transcends organizational boundaries); b) the relational and interactive nature of the process (LARSSON, BENGTSSON, HENRIKSSON et al., 1998; MUTHUSAMY and WHITE, 2005); c) knowledge as one of the main resources to be developed and transferred.

In spite of its importance as a source of innovation and competitiveness, the transfer of interorganizational knowledge is a process marked by challenges (SZULANSKI, 2000; CUMMINGS and TENG, 2003; EASTERBY-SMITH, LYLES and TSANG, 2008; PÉREZ-NORDTVEDT, KEDIA, DATTA et al., 2008). First, because transference implies connection between two or more organizations, which requires organizational, cultural, and relational barriers to be overcome in order for the exchange of knowledge to actually take place (LARSSON, BENGTSSON, HENRIKSSON et al., 1998; POWELL, 1998; MUTHUSAMY and WHITE, 2005). In addition, the process performance depends on the actual assimilation and application of the knowledge in the receiving company in order to generate the expected results. Therefore, more than a simple act of transferring knowledge from one context to another, transference is a process of social construction that requires the adaptation and transformation of external knowledge (ARGOTE and MIRON-SPEKTOR, 2011; MARTINKENAITE, 2011; ARGOTE and FAHRENKOPF, 2016).

Finally, the transfer of interorganizational knowledge, too, is influenced by the type of knowledge to be transferred. Tacit and explicit knowledge is transferred through different mechanisms and at different rates and, therefore, its nature must be considered at the moment of transference (ARGOTE, MC EVILY and REAGANS, 2003; CUMMINGS and TENG, 2003; JASIMUDDIN, 2007; VAN WIJK, JANSEN and LYLES, 2008; NONAKA, TOYAMA and HIRATA, 2008; NONAKA and VON KROGH, 2009). Finally, the selection of transfer mechanisms is a crucial activity in the process given its role of integrating organizations and alleviating the barriers between them. The training, the personal conversations and the manuals are some examples of these mechanisms (BJORKMAN, STAHL and VAARA, 2007; JASIMUDDIN, 2007; KHARABSHEH, 2007; EASTERBY-SMITH, LYLES and TSANG, 2008).

Regarding the type of knowledge, some researchers point out that such a resource is permeated by cultural aspects of the context of its origin and may seem unfamiliar and understandable in other environments (NONAKA, TOYAMA and HIRATA, 2003; 2008; NONAKA and VON KROGH, 2009). These characteristics tend to hinder the assimilation and application of knowledge by the receiving firm and, consequently, undermine the process of interorganizational knowledge transfer by preventing knowledge from being internalized and exploited (ARGOTE, MC EVILY and REAGANS, 2003; CUMMINGS and TENG, 2003; EASTERBY-SMITH, LYLES and TSANG, 2008; VAN WIJK, JANSEN and LYLES, 2008; BATTISTELLA, DE TONI and 
PILLON, 2016). Even if knowledge is codified in manuals and procedures, its full exploitation requires the transference of its tacit component, which is the experience possessed by the individual who produced such knowledge (LEMOS, 2008; VAN WIJK, JANSEN and LYLES, 2008).

In this perspective, a considerable number of researches call attention to the influence of the characteristics of the knowledge in the performance of the transference (SZULANSKI, 2000; ARGOTE, MC EVILY and REAGANS, 2003; CUMMINGS and TENG, 2003; JASIMUDDIN, 2007; EASTERBY-SMITH, LYLES and TSANG, 2008; VAN WIJK, JANSEN and LYLES, 2008; BOZEMAN, RIMES and YOUTIE, 2015; BATTISTELLA, DE TONI and PILLON, 2016). While some organizational knowledge can be easily codified and materialized, others are rooted in people, in business, and in culture, making articulation and use difficult. Thus, there are two forms of knowledge that complement each other and interact in the context of organizations: the tacit and the explicit (EASTERBY-SMITH, LYLES and TSANG, 2008; NONAKA, TOYAMA and HIRATA, 2003; 2008; NONAKA and VON KROGH, 2009).

Tacit knowledge is a combination of personal experiences, values and perspectives of individuals developed in a particular context and is related to the 'how' to do a certain task. His personal and subjective nature makes it difficult to verbalize and transfer knowledge (LEMOS, 2008; NONAKA, TOYAMA and HIRATA, 2008; NONAKA and VON KROGH, 2009). Therefore, sharing tacit knowledge implies social interaction, dialogue and exchange of experiences, allowing individuals to transform their know-how into information that is easier for others to understand. It requires a process of social construction, neither being able to replace nor to replicate exactly the original tacit knowledge (NONAKA and TAKEUCHI, 1997; EISENHARDT and SANTOS, 2002; GRANT, 2002). At the same time, the difficulty of making tacit knowledge explicit lies in its status as a protected and valuable asset for the organization and, therefore, an important source of value creation and competitiveness (BRESMAN, BIRKINSHAW and NOBEL, 1999; GRANT, 2002; SZULANSKI, 2000; SIMONIN, 2004).

Explicit knowledge, in turn, is one that can be articulated in the formal language and, because it is not associated with personal experiences, has few ambiguity characteristics. In this way, such knowledge has a more objective characteristic, and can be more easily materialized in manuals, norms, methodologies and artifacts, for example (KOGUT and ZANDER, 1993; BRESMAN, BIRKINSHAW and NOBEL, 1999; JASIMUDDIN, 2007; NONAKA, TOYAMA and HIRATA, 2008).

While tacit knowledge becomes collective through processes of socialization and collective learning (where the principal actor of the transfer is the person), the transfer of explicit knowledge can occur through more structured technological systems (BRESMAN, BIRKINSHAW and NOBEL, 1999; GOH, 2002; JASIMUDDIN, 2007; NONAKA, TOYAMA and HIRATA, 2008). Despite the distinction between tacit and explicit knowledge, they can be constantly transformed depending on the activities conducted within the organization. In fact, innovation depends on this continuous conversion of tacit knowledge into explicit (NONAKA, TOYAMA and HIRATA, 2008; NONAKA and VON KROGH, 2009).

The nature of knowledge has, therefore, important implications in the process of interorganizational knowledge transfer, since the more tacit the knowledge, the more difficult and complex the knowledge tends to be its sharing (ARGOTE, MC EVILY and REAGANS, 2003; LEMOS, 2008; EASTERBY-SMITH, LYLES and TSANG, 2008; VAN WIJK, JANSEN and LYLES, 2008). Besides the direct influence on process performance, the type of knowledge is a decisive variable in the choice of transfer mechanisms, according to the theoretical discussion in the next section.

\section{Transfer Mechanisms}

Transfer mechanism can be defined as the channel or the means by which knowledge is developed and/or shared between organizations (FERDOWS, 2006; JASIMUDDIN, 2007; BOZEMAN, RIMES and YOUTIE, 2015; BATTISTELLA, DE TONI and PILLON, 2016). Its purpose is to enable some type of connection (formal or informal) between institutions, allowing the transfer of knowledge to be realized. Personal and informal conversations, technical meetings, committees, communities of practice, interfirm teams, staff exchanges, trainings, manuals and procedures are some examples of mechanisms (JASIMUDDIN, 2007; KHARABSHEH, 2007; BEKKERS and FREITAS, 2008; EASTERBY-SMITH, LYLES and TSANG, 2008; LAWSON, PETERSEN, COUSINS et al., 2009; NECOECHEA-MONDRAGON, PINEDA-DOMÍNGUEZ and SOTO-FLORES, 2013).

The performance of interorganizational knowledge transfer depends on the presence of these mechanisms insofar as they represent, precisely, the channels through which knowledge is shared among organizations, favoring the approximation of the parties in the process and the overcoming of cultural barriers. In some cases, they allow the creation of a social community in 
which tacit and therefore valuable knowledge is transferred more easily (BRESMAN, BIRKINSHAW and NOBEL, 1999; ZAHRA and GEORGE, 2002; BJORKMAN, STAHL and VAARA, 2007).

Studies in the area indicate that, depending on the type of knowledge to be transferred, some mechanisms are more adequate. When transference involves predominantly tacit knowledge, the mechanisms of personalization are more appropriate, whereas when explicit knowledge prevails, coding methods are more efficient (GOH, 2002; ARGOTE, MC EVILY and REAGANS, 2003; CUMMINGS and TENG, 2003; JASIMUDDIN, 2007). In spite of this classification, the mechanisms can be used in a complementary way in several situations.

The personalization strategy presupposes that, given the subjective nature of tacit knowledge, personal and informal mechanisms may be more appropriate, since they allow individuals to interact in person, exchange experiences and learn from practical experience (SZULANSKI, 2000; NONAKA, TOYAMA and HIRATA, 2008; LAWSON, PETERSEN, COUSINS et al., 2009; NONAKA and VON KROGH, 2009). In this case, people are the main actors of the transference and the mechanisms vary between personal and informal meetings, group dialogues, communities of practices, exchange of personnel, among others (BRESMAN, BIRKINSHAW and NOBEL, 1999; GOH, 2002; JANSEN, VAN DEN BOSCH and VOLBERDA, 2005).

Communities of practice, for example, are an appropriate approach when tacit knowledge transfer is a priority. It consists of meeting people to address certain organizational issues, enhancing members' ability to think together, share knowledge and develop a sense of mutual obligation. This mechanism assists in overcoming individual and social barriers by circulating knowledge within and between organizations (DISTERER, 2001).

The exchange of people is also an appropriate mechanism for the transfer of tacit knowledge among firms, allowing the presence of individuals of the company of origin in the receiving organization (or vice versa), favoring the sharing of fundamental experiences for the application of external knowledge (EASTERBY-SMITH, LYLES and TSANG, 2008; LAWSON, PETERSEN, COUSINS et al., 2009; BATTISTELLA, DE TONI and PILLON, 2016). If the exchange does not occur, the receiving firm may face difficulties in understanding and / or applying knowledge, for example, not having expertise in the subject or not having been involved in the phases of knowledge creation in the company of origin, among other factors (EASTERBY-SMITH, LYLES and TSANG, 2008).

Therefore, the transfer of personnel, together with the technology materialized in a prototype or product, allows experiences to be shared and the knowledge adapted to its use in another context (ARGOTE and INGRAM, 2000; EASTERBY-SMITH, LYLES and TSANG, 2008; LAWSON, PETERSEN, COUSINS et al., 2009; BATTISTELLA, DE TONI and PILLON, 2016).

Personalization mechanisms consist of socialization activities in which individuals find, exchange experiences and learn from direct and personal experience (ZAHRA and GEORGE, 2002; JANSEN, VAN DEN BOSCH and VOLBERDA, 2005; BJORKMAN, STAHL and VAARA, 2007). Such practices contribute to raising the social connection and trust between individuals of different organizations, allowing the creation of an environment of convergent ideas and perspectives. In this direction, socialization is one of the essential activities in the transfer of tacit knowledge.

While the transfer of tacit knowledge requires intense personal contact and socialization processes, the transfer of more explicit forms of knowledge can occur through technological systems, structured processes and data repositories, which are some of the coding mechanisms. Given its characteristics - formal and easily codified knowledge - explicit knowledge can be transformed into artifacts such as rules, procedures, objects, materials, and manuals. These registers can be widely disseminated within and between organizations (BRESMAN, BIRKINSHAW and NOBEL, 1999; GOH, 2002; JASIMUDDIN, 2007; KHARABSHEH, 2007; NONAKA, TOYAMA and HIRATA, 2008; NONAKA and VON KROGH, 2009).

Based on the above, Box 1 brings together the main theoretical elements discussed here. 
Box 1

Type of knowledge and transfer mechanisms

\begin{tabular}{|l|l|l|}
\hline \multicolumn{1}{|c|}{ Item } & Classification & \multicolumn{1}{c|}{ Description } \\
\hline \multirow{3}{*}{ Knowledge } & Tacit & $\begin{array}{l}\text { - Experience and know-how } \\
\text { - Complex and subjective nature } \\
\text { - More difficult to be codified, understood and transferred }\end{array}$ \\
\cline { 2 - 3 } & \multirow{2}{*}{ Explicit } & $\begin{array}{l}\text { - Formal and impersonal nature } \\
\text { - Codified knowledge in manuals, procedures, flowcharts and prototypes }\end{array}$ \\
\hline \multirow{3}{*}{ Mechanism } & Personalization & $\begin{array}{l}\text { - Informal mechanism } \\
\text { - Suitable for transferring tacit knowledge } \\
\text { - Examples: exchange of people and communities of practice }\end{array}$ \\
\cline { 2 - 3 } & \multirow{2}{*}{ Codification } & $\begin{array}{l}\text { - Formal and structured mechanism } \\
\text { - Suitable for transferring explicit knowledge } \\
\text { - Example: Manuals, Flowcharts, Prototypes }\end{array}$ \\
\hline
\end{tabular}

Source: Elaborated by the authors.

Having discussed the theoretical bases of the research, the next section presents the methodological choices.

\section{RESEARCH METHOD}

In order to analyze the role of mechanisms in the transfer of knowledge between a Brazilian public research institution and its licensed companies, a qualitative research was chosen using the case study method (EISENHARDT, 1989; YIN, 2005). It is an appropriate research strategy since the transfer of interorganizational knowledge is a subject of recent research and there is still little convergence in relation to several aspects of this literature (MARTINKENAITE, 2011; BOZEMAN, RIMES and YOUTIE, 2015; BATTISTELLA, DE TONI and PILLON, 2016). In this sense, the qualitative case study allowed an in-depth analysis of the investigated phenomenon allowing an understanding of the transfer from the perspective of the subjects directly involved in the process, as well as the emergence of patterns, relations and factors behind the immediately observed.

A case study has as units of analysis people, situations, programs or organizations that exist naturally or are delimited intellectually by the researcher. The selection of the case in qualitative research is an important decision, as it may directly impact on the relevance of the study results. Therefore, this choice should not be random, but intentional, whose criteria must be oriented to the richness of the phenomenon (EISENHARDT, 1989; YIN, 2005).

Based on these premises, the selected empirical object was one of the research centers of the largest public institution of agricultural research in Brazil, named Research Institution for the purposes of this study. Founded in 1975, this research center has the mission of providing research, development and innovation solutions with an emphasis on maize and sorghum crops that contribute, in some way, to the sustainability of Brazilian agriculture. It should be pointed out that this case can be considered relevant because it is the largest public agricultural research institution in Brazil; for having as one of its main functions transfer technologies (corn cultivars) to the productive sector; and having extensive experience in technology transfer processes.

In terms of data collection instruments, the research used in-depth interviews, documents and field notes (EISENHARDT, 1989; YIN, 2005). Twelve interviews were conducted, ten with the collaborators of the research institution and two with professionals from the licensed companies (see Box 2). It should be pointed out that, since it is a question of qualitative research, whose main purpose is to understand the perception of the subjects interviewed in relation to the technology transfer, the collaborators who participated directly in this process were considered. Therefore, the objective is not statistical generalization, but a qualitative and holistic understanding of the process (YIN, 2005). 
Box 2

List of interviewees

\begin{tabular}{|c|c|}
\hline Interview & Research Institution \\
\hline 11 & Technological Business Area \\
\hline 12 & Technological Business Area \\
\hline 13 & Transfer Technology Office of Sete Lagoas \\
\hline 14 & Technological Business Area \\
\hline 15 & Transfer Technology Office of Sete Lagoas \\
\hline 16 & Technological Business Area \\
\hline 17 & Transfer Technology Office of Triângulo Mineiro \\
\hline 18 & Area of Communication and Technological Business \\
\hline 19 & Business Communication Area \\
\hline 110 & Research and Development Area \\
\hline \multicolumn{2}{|r|}{ Licensed Companies } \\
\hline 111 & Former director of a licensed company and current consultant \\
\hline 112 & Director of a licensed company \\
\hline
\end{tabular}

Source: Elaborated by the authors.

In relation to research questions, the interview script included questions related to the following categories: a) technology transfer process between the Research Institution and the licensed companies (history and description); $b$ ) the transfer mechanisms used and their characteristics (of personalization or codification); c) type of knowledge transferred between the parties; d) challenges and difficulties experienced in the process.

The twelve interviews were recorded and transcribed for the complete data storage (generating 350 pages of transcription), as well as to facilitate the organization and the treatment of the information based on categories of analysis previously evidenced. The interview phase ended when the lines of convergence were increasingly reinforced by the respondents and at the moment when the realization of new interviews stopped generating additional information relevant to the understanding of the phenomenon. That is, when theoretical or meaningful saturation was reached (EISENHARDT, 1989; BAUER and GASKELL, 2002). It is also worth noting that all the relevant observations captured by the researcher at the time of the interviews were recorded in field notes and inserted in the transcripts pertinent to each interviewee. After the conclusion of the interview phase, a panel was presented to present the evidence with the key informants to validate the results, thus conferring greater rigor and reliability in the research (EISENHARDT, 1989).

Regarding the documents, consultations were carried out with plans, institutional manuals; research and development bulletins; technical and managerial reports; information material (corn seeds) and the institution's website, which is very rich in terms of information (as indicated in the data analysis section).

For the examination of the data collected, we used the content analysis in which the researcher seeks to deeply understand the text, examine its various dimensions and construct inferences from it (BARDIN, 1944; BAUER and GASKELL, 2002; FLICK, 2009). To facilitate content analysis, Flick (2009) suggests the development of analysis categories designed on the basis of literature and reviewed in light of the research evidence. Having developed the main theoretical categories of the study, the researcher can organize the data according to these constructs, which allows him to stick to the main variables of interest of the research.

Based on the above, the following categories of analysis were established in the research carried out: technological transfer process; nature of knowledge; tacit and explicit knowledge; transfer mechanisms; customization and coding mechanisms. Thus, the data obtained were organized according to such categories, thus facilitating their codification and interpretation 
(EISENHARDT, 1989). Thus, it was possible to compare the perception of different actors about the same factor, as well as to perform the triangulation of sources of evidence, that is, to compare the data obtained from different sources of evidence, conferring greater reliability and quality in the results of search. This technique of articulating multiple sources of evidence for the analysis of the same phenomenon is one of the types of triangulation used in this research (JICK, 1979; EISENHARDT, 1989).

Once the methodological choices are presented, the next section considers the analysis of the empirical data.

\section{DATA ANALYSIS}

\section{Type of knowledge and transfer mechanisms of the Research Institution}

As pointed out in the theoretical review, a relevant factor in the interorganizational knowledge transfer is the nature of the knowledge involved in the process, as well as its influence in the selection of transfer mechanisms. The focus of empirical research was on the transfer of one of the most important technologies produced by the Research Institution (corn cultivars), which is one of the main cereals cultivated in the world and the second most produced grain in Brazil (behind soybean only). Thus, the maize seed or cultivar is the technology transfer vehicle that is produced within the scope of the Research Institution and which reaches the licensed companies to be multiplied and spread on the market (documents 8, 12, 14).

The empirical data show that maize has undergone considerable changes over the last decades, from the point of view of genetic improvement $(R \& D)$, as well as the development of new production and management practices, increasing the level of complexity of the technology.

Among these changes, the genetic variability and the different types of cultivar that can be generated (single, double, triple hybrid) stand out; as well as the diversity of fertilization and production techniques (document 8). For example, in the 2014/2015 crop, for example, the Research Institution made 478 corn seeds available (11 more than in the previous crop): 292 transgenic and 186 conventional.

In addition, maize can be used to meet the demands of different purposes and geographic regions, and must therefore be adaptable to these peculiarities (documents 4,12 ). The following report illustrates this complexity of the investigated technology:

And in our case, corn, is a biological thing. And then the same cultivar, depending on the company and the region, it may behave differently, it may be resistant to a disease here and may not be there. So today I think this is much more complex. So corn may change over time, the same product may change according to the conditions. So, this transfer is more complex (E12).

In this sense, the empirical data indicate that the corn cultivar has a certain level of complexity and the process of research and development of maize tends to be complex, demanding a body of highly qualified researchers in several specialties (zootechnicians, biologists, agronomists, geneticists, etc.) - documents 6, 13, 15, 16-; as well as the involvement of the licensed companies in the research process, in order to facilitate the internalization, on their part, of the tacit knowledge related to corn application. In the literature, the recipient company may have difficulty using the acquired technology, compromising the effectiveness of the transfer (BRESMAN, BIRKINSHAW and NOBEL, 1999; CUMMINGS and TENG, 2003; VAN WIJK, JANSEN and LYLES, 2008). From the above, the more complex (tacit) knowledge, the more difficult it tends to be to transfer between different organizations (NONAKA, TOYAMA and HIRATA, 2008; NONAKA and VON KROGH, 2009), indicating the need to adopt socialization mechanisms.

In addition to directly impacting the performance of the transfer, the nature of knowledge also influences the choice of mechanisms (JASIMUDDIN, 2007; KHARABSHEH, 2007; BATTISTELLA, DE TONI and PILLON, 2016). In the context of the Research Institution investigated, the following mechanisms were generally identified that can be used in technological transfer processes: a) Observation unit; b) Field days; c) Technical meetings; d) Training and Visitation System; e) knowledge transfer through mass communication channels (website, technical bulletins, radio, television and newspaper articles) documents 3, 14, 17. 
The observation unit is a mechanism used by the Research Institution to validate the technologies and knowledge produced by the institution with its target audience. At this stage of the $R \& D$ process, the Research Institution cedes a new maize cultivar to licensed companies that test and evaluate the performance of the technology in its own field, a step that can be followed by researchers of the Research Institution. Once the tests have been carried out in the field of the licensed company, the Research Institution obtains important information for the improvement of the technology before its actual transference (documents 3, 8).

If the observation unit is usually carried out in the course of the $R \& D$ process, the field day is conducted after the maize cultivar is fully developed and available for transfer to the market. Field day, therefore, consists of the demonstration, in the field, of the characteristics and the way of handling of the technology produced by the Research Institution for technicians and businessmen of the licensed companies. Field days may occur in the Research Institution or in the field of licensed companies, but involve the practical experimentation of technologies in the presence of future users (document 3, 9).

Another way to transfer the knowledge produced by the Research Institution is through technical meetings, which are faceto-face meetings held to plan activities, identify demands and evaluate the results achieved in a meeting with researchers from the Research Institution and professionals from licensed companies. Such meetings are made based on specific requests requested by the Research Institution or by the licensed companies (document 9).

The Training and Visitation System is one of the most complete transfer mechanisms insofar as it can integrate all the methods mentioned above. Although such a mechanism has no focus on licensed enterprises, but on all actors in the maize production chain, it can be developed with emphasis on recipient firms. The "training" represents the training actions of the agents involved, through courses, field days, seminars, sending of folders, technical bulletins, among others, while the "visit" consists of monitoring, by researchers of the Research Institution, of technology applications in the field of licensed business (document 1 ).

Finally, a very common form used by the Research Institution to transfer knowledge is through mass communication channels. Frequently, guidelines, products and technologies are disseminated by website, scientific articles, technical bulletins, radio and television programs, newspapers and magazines, local and national (documents 3, 10, 11). An important tool in this context is the Information Agency of the Research Institution, which consists of a web platform that enables the registration, dissemination and access to the knowledge generated in the Research Institution. The information is organized in a branched structure, called Tree of Knowledge, which contemplates a classification according to themes, beginning with generic knowledge and reaching the most specific ones. In addition, the Agency provides the user with access to information resources in full (articles, books, images, audios, videos) and thus constitutes an important collection of knowledge of the Research Institution (document 5).

Analyzing the nature and characteristics of the mechanisms described above, it can be observed that they can vary between the most suitable to transfer tacit knowledge (personalization mechanisms), and those more efficient in the sharing of explicit knowledge (coding mechanisms), as can be observed in Figure 1. As will be detailed later, the empirical data reveal that the Research Institution prioritizes the use of mass communication channels (that is, there is a greater incidence of mechanisms of this nature), using few mechanisms that favor the transfer of knowledge tacit (like system training and visiting and observation units). 
Figure 1

Mechanisms used by the Research Institution

\begin{tabular}{|c|c|c|c|c|}
\hline \multirow[b]{2}{*}{$\begin{array}{c}\text { Mass Communication } \\
\text { Channels }\end{array}$} & \multicolumn{2}{|c|}{ MECHANISMS } & \multirow[b]{2}{*}{$\begin{array}{c}\text { Observation } \\
\text { units }\end{array}$} & \multirow[b]{2}{*}{$\begin{array}{c}\text { Training and } \\
\text { Visitation System }\end{array}$} \\
\hline & $\begin{array}{l}\text { Technical } \\
\text { Meetings }\end{array}$ & $\begin{array}{l}\text { Field } \\
\text { Days }\end{array}$ & & \\
\hline \multirow[t]{2}{*}{ EXPLICIT } & & & & TACIT \\
\hline & & INOWL & & \\
\hline
\end{tabular}

Source: Elaborated by the authors.

Considering the complexity of the R \& D technology and process of maize cultivar (previously discussed), it was expected the intense use of customization mechanisms, in addition to the coding mechanisms. In other words, in addition to the transfer of codified knowledge in maize seed, the data indicate that it would be appropriate to systematically conduct observational and training units/visits, insofar as it would allow exchange of experiences between the parties, practical experimentation with the new technology and sharing of tacit knowledge (SZULANSKI, 2000; NONAKA, TOYAMA and HIRATA, 2008; NONAKA and VON KROGH, 2009), allowing a better understanding and application of the maize cultivar by the licensed companies. However, the research findings reveal that such mechanisms (especially personalization) have not been systematically used (E1, E3, E4, E6):

The Research Institution should teach companies, especially firms with little experience, all aspects involved in the production of maize such as crossbreeding, simple corn production, double corn, triple as the field should be set, characteristics of the field, how many lines of male, of female, how far between plants, among others. The company has to know the importance of each of these variables at the time of production. This is a role that the Institution can fulfill. So, they can do this and it has not been done (E2).

There are indications that until the 1990s, the Research Institution operated in the licensed companies more intensively, through frequent technical visits in the fields of the graduates, guiding / qualifying the company technicians and solving problems together. However, there was a change in the partnership model between the Research Institution and the companies, which, in the view of the interviewees, reduced social interaction and personal approximation between the parties, as well as decreased the use of personalization mechanisms to transfer tacit knowledge) (E1, E3, E4, E6). In spite of this, the use of coding mechanisms (which allows for the transfer of knowledge through mass communication channels) has been intensified, disregarding in some way the complexity of the technology in question.

With regard to technical meetings, for example, respondents suggest that it is a time to deal with purely formal issues, not helping to integrate the parties in the process (E4), an opinion that is also shared by the licensed companies. In the interviewees' perceptions, there are more efficient mechanisms than meetings, as this report explains: "There are field practices that are much more productive than a meeting, where everyone comes from far and sits in a room." (E11). Finally, meetings that do not occur systematically (only once or twice a year) do not favor the social bond and the exchange of experiences between professionals of the Research Institution and the licensed companies (E1, E4).

There are meetings to define formal aspects such as discussions of the work plan, quantity of seeds to be produced, among others. However, meetings to exchange experiences between the Research Institution and the licensees do not occur (E4).

In terms of training, they are carried out based on demands pointed out by the licensed companies or at the initiative of the Research Institution itself when launching a new cultivar or identifying a frequent problem in the field of licensed companies, for example (E3, E8, E11). Nevertheless, the empirical data indicate that the training also has not fulfilled its role in the transfer 
of knowledge. On the one hand, the Research Institution claims that some of the companies have not participated in the training (generally the larger ones) or that the demands of the graduates for training are not coming to the knowledge of the Research Institution (E1, E3, E6, E10). On the other hand, the licensed companies indicate that the training is sporadic and that the methodology used by the Research Institution is not adequate, since it does not involve experimentation and application activities. Thus, there are indications that the training serves more to transmit information (explicit knowledge) than to effectively enable (E10, E11), as the reports indicate:

It has a lot of information we need to know, business is complex. It is a confusion that demands experimentation, comparison. And this has to be systematized to pass the graduates. But it is discontinuous (E10).

The training does not take place permanently, but once or twice a year (E10).

Regarding the Observation Units, the empirical data indicate that the number of licensed companies that have conducted this experiment in their own fields is low and, when conducting, do not provide feedback to the Research Institution regarding the performance of the materials. According to the researchers, such information has seen "industrial secrecy" for companies that do not want to see this data disseminated to competing firms (E1, E3, E4, E6, E12):

[...] the companies that are interested in making the observation unit, the best, they usually hold this information. There have been cases where we visited very good companies, with an excellent observation unit and the data did not come here. And they have another extreme too, companies that do not make the unit of observation (E12).

In addition, the idea is that, through the implementation of Observation Units, the parties could exchange information and experiences on the performance of technologies, field problems, among other issues, in order to return important insights to $R$ \& $D$, which has not been fulfilled (E2, E3, E5).

It is also worth noting that the frequency of use of certain mechanisms is also considered to be short of what is necessary, according to some reports. In other words, sporadic training, annual events or isolated initiatives are not enough to promote the sharing of knowledge between the Research Institution and the licensed companies, especially the tacit (E3, E10). Therefore, the data indicate that the methodology of training, visits and other mechanisms needs to be systematic, unlike what happens in practice, as evidenced by this report: "After the events, there is no type of reinforcement by the Research Institution. You do not have a follow up to know if the company is doing well" (E3).

It should also be noted that licensed companies value the use of personalization mechanisms (such as field days and technical visits by Research Institution researchers in their fields) rather than formal and impersonal mechanisms (such as technical reports and manuals, closer to what literature indicates as mechanisms of codification), that is, "[...] is not a page that will tell how to produce efficiently. Their participation in our activities is necessary and this we do not have today" (E1).

Thus, from the perspective of the licensed companies, there is a lack of technical support, personal support and critical information on the technologies launched by the Research Institution, as explained in the following section:

I would very much like to receive more support from my partner (from the Research Institution). Missing information. When we get a new maize cultivar to produce, we lack basic information [...] To work with the product I have to have access to all this information. So, the technological package of the Research Institution still has fractures, there are flaws that needed to be better worked. But then, when you arrive at the Research Institution and say "we need someone to do it," and then the "push, push' begins. Go to research, go to another area, etc. (E11).

Based on the foregoing, it is observed, on the one hand, that companies have not used the mechanisms developed by the Research Institution and, on the other, there is a perception, by the licensed companies, that the mechanisms used by the institution are not adequate (and the frequency with which they are performed). Consequently, mechanisms that could contribute to a greater effectiveness in knowledge transfer (integrating the parties in the process, minimizing cultural differences 
and sharing tacit knowledge) have not fulfilled their role in the process (JANSEN, VAN DEN BOSCH and VOLBERDA, 2005; JASIMUDDIN, 2007; KHARABSHEH, 2007; BATTISTELLA, DE TONI and PILLON, 2016).

In this direction, the Box 3 gathers some aspects that are configured as challenges in the process of knowledge transfer between the Research Institution and its licensed companies, with regard to the type of knowledge and transfer mechanisms:

\section{Box 3}

Findings related to the Type of Knowledge and Transfer Mechanisms

\begin{tabular}{|c|l|}
\hline Factor & \multicolumn{1}{c|}{ Description of findings } \\
\hline $\begin{array}{c}\text { Type of } \\
\text { Knowledge }\end{array}$ & $\begin{array}{l}\text { - Complexity of the investigated technology (of the maize cultivar) and its R\&D process. } \\
\text { - Corn is a complex knowledge because although the seed is the main vehicle of technology transfer, } \\
\text { there is tacit knowledge used in the R\&D process that are fundamental for the later application of the } \\
\text { technology by the licensed companies. }\end{array}$ \\
\hline Mechanisms & $\begin{array}{l}\text { - More intensive use of coding mechanisms (transfer of knowledge through technical reports, manuals } \\
\text { and mass communication channels). } \\
\text { - Low utilization of customization mechanisms. } \\
\text { - The licensed companies have not participated in the mechanisms provided by the Research Institution. }\end{array}$ \\
\hline
\end{tabular}

Source: Elaborated by the authors.

\section{FINAL CONSIDERATIONS}

Based on the theoretical perspective of the interorganizational knowledge transfer, this research analyzed the role of the mechanisms in the performance of knowledge transfer between a public agricultural public institution and its licensed companies. The results of the study show that, despite the diversity of available mechanisms (ranging from meetings, courses, visits, field days, observation units), the transfer process between the Research Institution and the companies is characterized by the more intensive use of coding mechanisms (rather than the methods of personalization, which are fundamental in the transfer of tacit knowledge).

Thus, the findings of the study reveal that the frequency with which socialization activities and practical experimentation involving the Research Institution and the licensed companies are low, disregarding in some way that the transfer of interorganizational knowledge goes beyond a simple action of transferring knowledge from one context to another, as the term "knowledge transfer" semantically suggests.

As a counterpoint to this understanding, the research results highlight the difficulty of "mobilizing" knowledge among different organizational contexts in the absence of adequate transfer mechanisms. Therefore, the transfer of interorganizational knowledge must be conceived as a relational process that requires joint learning, especially when the type of knowledge involved has a complex nature, as is the case of maize cultivars. Thus, even if the Research Institution encodes this knowledge in manuals, publications and fact sheets, such actions do not seem sufficient to allow an effective exploitation of the technology in the field of licensed companies.

From the above, there is evidence of gaps in relation to the type of transfer mechanism used by the Research Institution, as well as in relation to the frequency with which they are carried out, which may generate bottlenecks in the interorganizational knowledge transfer process, among them: low integration between the source and recipient institutions, making dialogue and the relationship between the parties difficult; emergence of relational conflicts due to cultural differences between institutions; difficulties in the application of the technology by the licensed companies, inhibiting the process innovation potential. Such difficulties could be alleviated by the adoption of personalization mechanisms by allowing for ample personal interaction between the parties, sharing of experiences and joint learning, allowing the overcoming of cultural and relational barriers between the parties. Therefore, personalization mechanisms are essential variables when thinking about successful knowledge transfer processes, especially when the knowledge object of the transfer has complex nature. 
The results presented here converge with some studies in the area of "knowledge transfer" that signal that tacit knowledge sharing requires the use of personalization mechanisms and that, in the absence of adequate mechanisms, technology transfer tends to face considerable challenges

Regarding the theoretical contribution of this study, the research contributes in some way to the advance in the understanding of the influence of the mechanisms in the performance of the interorganizational knowledge transfer, also indicating that the inadequate choice by the type of mechanisms has negative implications for the success the process. From the empirical point of view, the understanding of the transfer process and some variables that affect it can contribute with subsidies for the Research Institution and the licensed companies improve the sharing of knowledge between the parties, since there is evidence of difficulties in the process.

Specifically, in terms of mechanisms, the results of the study point out that it may be appropriate to develop activities and capacities with a focus on licensed companies, since, although the institution serves several publics, agricultural companies that acquire their technologies are central agents in the dissemination of their innovations by the agricultural chain, besides giving financial sense to the resources invested in R\&D. It is also suggested that the Research Institution stimulate the continuous realization of personalization mechanisms that allow the exchange of experiences and the sharing of tacit knowledge between source and reception, due to the complex nature of shared technology.

In this perspective, the systematic realization of personalization mechanisms can contribute to the performance of the transfer, by attenuating several critical problems observed in the case investigated, that is, by widening the social integration between the source and the recipients, by minimizing the perception of cultural distance between parties and allowing the sharing of tacit knowledge related to technology, enabling a more effective exploitation of technology by licensed companies.

\section{ACKNOWLEDGEMENTS}

National Council for the Improvement of Higher Education - Brazil (CAPES) for financial support.

Research Support Foundation of Minas Gerais (FAPEMIG) for financial support.

National Council for Research and Development (CNPq) for support. 


\section{REFERENCES}

ARGOTE, L.; FAHRENKOPF, E. Knowledge transfer in organizations: the roles of members, tasks, tools, and networks. Organizational Behavior and Human Decision Processes, v. 136, p. 146-159, 2016.

ARGOTE, L.; INGRAM, P. Knowledge transfer: a basis for competitive advantage of firms. Organizational Behavior and Human Decision Processes, v. 82, n. 1, p. 150-169, 2000.

ARGOTE, L.; MC EVILY, B.; REAGANS, R. Managing knowledge in organizations: an integrative framework and review of emerging themes. Management Science, v. 49, n. 4, p. 571-582, 2003.

ARGOTE, L.; MIRON-SPEKTOR, E. Organizational Learning: from Experience to Knowledge. Organization Science, v. 22, n. 5, p. 1123 1137, 2011.

BARDIN, L. Análise de conteúdo. Lisboa: Edições Setenta, 1994.

BATTISTELLA, C.; DE TONI, A.F.; PILLON, R. J. Inter-organisational technology/knowledge transfer: a framework from critical literature review. The Journal of Technology Transfer, v. 41, n. 5, p. 11951234, 2016.

BAUER, M. W.; GASKELL, G. Pesquisa Qualitativa com Texto, Imagem e Som: um manual prático. 2. ed. Petrópolis: Vozes, 2002, 516 p.

BEKKERS, R.; FREITAS, I. M. B. Analysing knowledge transfer channels between universities and industry: To what degree do sectors also matter? Research Policy, v. 37, p. 1837-1853, 2008.

BJORKMAN, I.; STAHL, G. K.; VAARA, E. Cultural differences and capability transfer in cross-border acquisitions: the mediating roles of capability complimentarily, absorptive capacity and social integration. Journal of International Business Studies, v. 38, n. 4, p. 658-672, 2007.

BOZEMAN, B.; RIMES, H.; YOUTIE, J. The evolving state-of-the-art in technology transfer research: revisiting the contingent effectiveness model. Research Policy, v. 44, n. 1, p. 34-49, 2015.

BRESMAN, H.; BIRKINSHAW, J.; NOBEL, R. Knowledge transfer in international acquisitions. Journal of international Business Studies, v. 30, n. 3, p. 439-462, 1999.

CUMMINGS, J. L.; TENG; B. S. Transferring R\&D Knowledge: the key factors affecting Knowledge transfer success. Journal of Engineering and Technology Management, v. 20, p. 39-68, 2003.

DINIZ, D. M. O papel dos fatores antecedentes e dos mecanismos no processo de transferência de conhecimento interfirmas: um estudo de caso na Embrapa milho e sorgo. 2011. Master Thesis (Master Degree in Administration) - Pontifícia Universidade Católica de Minas Gerais, Belo Horizonte, 2011.

DISTERER, G. Individual and social barriers to knowledge transfer. In: INTERNATIONAL CONFERENCE ON SYSTEM SCIENCES, 34., 2001, Hawaii Proceedings... 2001.

EASTERBY-SMITH, M.; LYLES, M. A.; TSANG, E. W. K. Interorganizational knowledge transfer: current themes and future prospects. Journal of Management Studies, v. 45, n. 4, p. 677-690, June 2008.

EISENHARDT, K. M. Building Theories from Case Study Research. Academy of Management Review, n. 4, v. 14, 1989.
FERDOWS, K. Transfer of changing production know-how. Production and Operations Management, v. 15, n. 2, p. 1-9, 2006.

FLICK, U. Introdução à pesquisa qualitativa. Porto Alegre: Artmed, 2009. 405 p.

$\mathrm{GOH}, \mathrm{S}$. C. Managing effective knowledge transfer: an integrative framework and some practice implications. Journal of Knowledge Management, v. 6, n. 1, p. 22-30, 2002.

GRANT, R. M. The knowledge-based view of the firm. In: CHOO, C. W; BONTIS, N. (Eds.). The strategic management of intellectual capital and organizational knowledge. Oxford: Oxford University Press, 2002. p. 133-148.

INSTITUTO BRASILEIRO DE GEOGRAFIA E ESTATÍSTICA - IBGE. Tabelas 2016-Sistema de contas nacionais: Brasil. 2016. Available at: <https:// www.ibge.gov.br/estatisticas-novoportal/economicas/servicos/9052sistema-de-contas-nacionais-brasil.html?=\&t=resultados $>$. Accessed on: Dec. 18, 2018.

JANSEN, J. J. P.; VAN DEN BOSCH, F. A. J.; VOLBERDA, H. W. Managing potential and realized absorptive capacity: how do organizational antecedents matter? Academy of Management Journal, v. 48, n. 6, p. 999-1015, 2005.

JASIMUDDIN, Sajjad M. Exploring knowledge transfer mechanisms: the case of a UK-based group within a high-tech global corporation. International Journal of Information Management, v. 27, p. $294-$ 300, 2007.

JICK, T. D. Mixing qualitative and quantitative methods: triangulation in action. Administrative Science Quarterly, v. 24, 1979.

KHARABSHEH, R. A. A. Model of Antecedents of Knowledge Sharing. The eletronic Journal of Knowledge Managemnet, v. 5, p. 419-426, 2007.

KOGUT, B., ZANDER, U. Knowledge of the firm and the Evolutionary Theory of the multinational corporation. Journal of International Business Studies, v. 24, p. 625-645, 1993.

LARSSON, R. et al. The interorganizational learning dilemma: collective knowledge development in strategic alliances. Organization Science, v. 9, n. 3, p. 285-305, 1998.

LAWSON, B. et al. Knowledge sharing in interorganizational product development teams: the effect of formal and informal socialization mechanisms. Journal Product Innovation Management, v. 26, n. 2, p. 156-172, 2009.

LEMOS, B. N. Fatores relevantes de sucesso à transferência do conhecimento tácito: evidências empírico-exploratórias em uma empresa petrolífera brasileira. 128 p. 2008. Master Thesis (Master Degree in Management) - Escola Brasileira de Administração Pública e de Empresas, Fundação Getulio Vargas, Rio de Janeiro, 2008.

LOVE, J. H.; ROPER, S. The determinants of innovation: R\&D, technology transfer and networking effects. Review of Industrial Organization, v. 15, p. $43-64,1999$.

MARTINKENAITE, I. Antecedents and consequences of interorganizational knowledge transfer: emerging themes and openings for further research. Baltic Journal of Management, v. 6, n. 1, p. 53-70, 2011. 
Interorganizational knowledge transfer mechanisms: a study in the largest Brazilian institution of agricultural research

MUTHUSAMY, S. K.; WHITE, M. A. Learning and knowledge transfer in strategic alliances: a social exchange view. Organization Studies, v. 26, n. 3, p. 415-441, 2005.

NECOECHEA-MONDRAGON, $\mathrm{H}$. et al. A conceptual model of technology transfer for public universities in Mexico. Journal of Technology Management \& Innovation, Santiago, v. 8, n. 4, p. 24-35, 2013.

NONAKA, I.; TAKEUCHI, H. Criação de conhecimento na empresa: como as empresas japonesas geram a dinâmica da inovação. Rio de Janeiro: Campus, 1997. 358p.

NONAKA, l.; TOYAMA, R.; HIRATA, T. Teoria e casos de empresas baseadas no conhecimento: managing flow. Porto Alegre: Bookman, 2003. 303 p.

NONAKA, I.; TOYAMA, R.; HIRATA, T. Managing Flow: a process theory of the knowledge-based firm. New York: Palgrave Macmillan, 2008.

NONAKA, I.; VON KROGH, G. Tacit knowledge and knowledge conversion: controversy and advancement in organizational knowledge Creation Theory. Organization Science, v. 20, n. 3, p. 635-652, 2009.
PÉREZ-NORDTVEDT, L. et al. Effectiveness and Efficiency of CrossBorder Knowledge Transfer: An Empirical Examination. Journal of Management Studies, v. 45, n. 4, p. 714-744, June 2008.

POWELL, W. W. Learning from collaboration: knowledge and networks in the biotechnology and pharmaceutical industries. California Management Review, v. 40, n. 3, p. 228-240, 1998.

SIMONIN, B. An empirical investigation of the process of knowledge transfer in international strategic alliances. Journal of International Business Studies, v. 35, n. 5, p. 407-427, 2004.

SZULANSKI, G. The process of knowledge transfer: A diachronic analysis of stickiness. Organizational Behavior and Human Decision Processes, v. 82, p. 9-27, 2000.

VAN WIJK, R.; JANSEN, J. J. P.; LYLES, M. A. Inter and intraorganizational knowledge transfer: a meta-analytic review and assessment of its antecedents and consequences. Journal of Management Studies, v. 45, n. 4, p. 830-853, June 2008.

YIN, R. K. Estudo de caso: planejamento e métodos. 3. ed. Porto Alegre: Bookman, 2005.

ZAHRA, S. A.; GEORGE, G. Absorptive Capacity: a review, reconceptualization and extension. Academy of Management Review, v. 27, p. 185-203, 2002.

\section{Daniela Martins Diniz}

ORCID: https://orcid.org/0000-0001-8535-8703

Adjunct Professor of the Federal University of São João Del Rei (UFSJ) linked to the Department of Administrative and Accounting Sciences (DECAC); Professor of the Professional Master's Degree in Intellectual Property and Technology Transfer for Innovation at the Federal University of São João Del Rei (UFSJ); Doctor in Administration from the Federal University of Minas Gerais (UFMG); Master in Business Administration from the Pontifical Catholic University of Minas Gerais (PUC Minas), São João del Rei-MG, Brazil. E-mail: danidiniz@ufsj.edu.br

Fabricio Molica de Mendonça

ORCID: http://orcid.org/0000-0002-3175-1064

Bachelor of Business Administration from the Federal University of Viçosa (UFV); Master's degree from the Federal University of Viçosa (UFV); Ph.D. in Production Engineering from the Federal University of Rio de Janeiro (UFRJ); Collaborator and researcher at the Federal University of Rio de Janeiro (UFRJ); Professor of the Academic Master's Program in Administration of the Federal Center of Technological Education of Minas Gerais (CEFET-MG); Professor of the Master's Program in Intellectual Property and Technology Transfer for Innovation and Associate Professor II of the Federal University of São João Del-Rei (UFSJ), São João del Rei-MG, Brazil. E-mail: fabriciomolica@ufsj.edu.br

Fátima Bayma de Oliveira

ORCID: https://orcid.org/0000-0001-5158-9546

Doctor in Education from the Federal University of Rio de Janeiro (UFRJ); Master of Public Administration from the University of Connecticut (USA); Bachelor in Public Administration from the Brazilian School of Public Administration and Business of the Getulio Vargas Foundation (FGV EBAPE); Full Professor of the Getulio Vargas Foundation (FGV EBAPE) in the Masters and Doctoral courses in Administration, Rio de Janeiro - RJ, Brazil. E-mail: fatima.oliveira@ fgv.br

Anderson de Souza Sant'Anna

ORCID: https://orcid.org/0000-0001-6537-6314

Adjunct Professor at the School of Business Administration of São Paulo of the Getulio Vargas Foundation (FGV EAESP); Researcher Productivity in Research of the National Council of Scientific and Technological Development (CNPq); Post-doctoral program for the Graduate Program in Psychoanalytical Theory of the Federal University of Rio de Janeiro (UFRJ); Doctor of Business Administration; Doctor of Architecture and Urbanism; Master in Business Administration; Specialist in Strategic Management; Bachelor of Business Administration from the Federal University of Minas Gerais (UFMG), São Paulo - SP, Brazil. E-mail: andersonsant@icloud.com 


\section{APPENDIX}

Appendix A

List of documents consulted at the Research Institution

\begin{tabular}{|c|c|c|}
\hline $\mathrm{N}$ & Title & Type of Document \\
\hline 1 & Training and Visitation Manual & Research Institution Website \\
\hline 2 & Technological Business Policy & Institutional policy \\
\hline 3 & Transfer of technology to the Research Institution & Institutional document \\
\hline 4 & Transfer of technology in practices promoting maize grain yield & Institutional document \\
\hline 5 & Information Agency: a tool for knowledge management in RD\&I companies & Article \\
\hline 6 & Considerations on the maintenance of corn germplasm in Brazil & Institutional document \\
\hline 7 & Promotion of information on technologies and organic products & Article \\
\hline 8 & Pre-improvement, improvement and post-improvement: strategies and challenges & Book \\
\hline 9 & Transfer of technology for cultivars developed by the Research Institution & Article \\
\hline 10 & Management report & Institutional document \\
\hline 11 & V Master Plan of the Research Institution (2008-2011-2023) & Institutional plan \\
\hline 12 & Licensing agreement for production and commercialization of seed of BRS maize & Institutional document \\
\hline 13 & Transfer of technology in practices promoting maize grain yield & Institutional document \\
\hline 14 & Guidelines for technology transfer: incubation model & Institutional document \\
\hline 15 & $\begin{array}{l}\text { System of evaluation of the social impact of agricultural technological innovation } \\
\text { (Ambitec-Social) }\end{array}$ & R\&D report \\
\hline 16 & Pre-improvement, improvement and post-improvement & Book \\
\hline 17 & Training and Visitation Deployment Manual & Institutional manual \\
\hline
\end{tabular}

Source: Elaborated by the authors. 